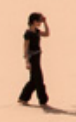

\section{A 'Pessoptimistic' View of Chinese Labour NGOs}

Ivan Franceschini

Kevin Lin

In the wake of the 2015 crackdown on labour NGOs, pessimism about the future of Chinese civil society has been unavoidable even for the most assured optimists. Still, pessimism and optimism in discussions of Chinese labour NGOs have roots that go far deeper than these latest turn of events. In this essay, Ivan Franceschini and Kevin Lin take stock of the existing literature and reconsider the debate in light of the latest developments, proposing a possible synthesis between 'optimistic' and 'pessimistic' views.
Sola, Alone.

PC: Alexandra Antonini.
'We've entered a grey area: we're not organisations anymore, and maybe in the future we'll be reduced to only a few

individuals.'

T his was the ominous prediction of one Chinese labour activist in Shenzhen in 2016. If we consider that these words were proffered in the midst of the worst crackdown that labour NGOs had experienced since their appearance in China two decades before, his pessimism was warranted. A few months earlier, with little warning, the police in Guangdong province had arrested a couple dozen labour activists in various organisations, bringing charges against five of them. At the time of the interview, it was still unclear what would happen to the detained activists-only later would they be sentenced to detention for 18 to 36 months, suspended in all cases but one-and tension was running high within the community of Chinese labour NGOs. In addition, there was widespread concern that the enforcement of the Foreign NGO Management Law the following year would restrict or even cut off foreign funding for these organisations and, thus, jeopardise their very survival (Franceschini and Nesossi 2017). 
At such a bleak time, pessimism was unavoidable even for the most assured optimists. Still, pessimism and optimism in discussions of Chinese labour NGOs-either among activists or among scholars-have roots that go far deeper than these latest turn of events. Proponents of negative and positive views of labour NGOs have been sparring with each other for at least a decade. In the latest addition to the discussion, Chris Chan (2018) has critiqued both mindsets. In his opinion, 'over-optimism or over-pessimism can be harmful in hard times', with optimists 'preferring not to face the mistakes of their strategies' and pessimists accusing labour NGOs of undermining worker solidarity and arguing that they are no longer needed, when this is, in fact, not the case. However, it is important to acknowledge that labour NGOs are not static entities, but rather dynamic institutions that change over time, adapting to the shifting political context. For this reason, any analysis of labour NGOs should take into account the changing environment, and evaluations of their 'effectiveness' must necessarily vary markedly over time.

In this essay, we take stock of the existing literature and reconsider it in light of the latest developments. In the next section we begin by outlining the main features of the scholarly debate over labour NGOs. This is followed by a description of how in recent years some organisations have attempted to adopt a new approach. We conclude the essay by offering some remarks on the prospects for the survival of these organisations going forward.

\section{A Polarised Field}

The earliest labour NGOs appeared in China in the mid-1990s, benefitting from an inflow of foreign funding in the wake of the Chinese government's more open stance towards civil society (Chan 2013; Howell 2008; Pun and Chan 2004). Since the beginning, these organisations have focussed on four kinds of activities: a) the establishment of worker centres, which usually include a small library and offer special interest classes, educational classes, and recreational activities; b) the provision of legal consultation services and, in some rare cases, legal representation; c) outreach programmes on labour rights; and d) the social surveys and policy advocacy (Chan 2013; Xu 2013). It has been this choice of limiting themselves to such nonconfrontational activities, adopting a strictly legalistic conception of rights-instead of focussing on promoting the interests of the workers or aggressively pushing for new progressive laws and regulations through collective struggle-that has attracted scrutiny in the existing literature.

Most scholars have maintained a positive assessment of these organisations' focus on community building and legal mobilisation. For instance, Xu Yi has contended that the legal mobilisation strategy of many labour NGOs has important political implications, since 'through legal mobilising, labour NGOs foster consciousness and the skills of organising [among the workers]' (2013, 250). Diana Fu has argued that these organisations are actually resorting to 'disguised collective actions,' which she defines as 'a form of organised activism in which civil society groups play a vital but under-the-radar role in coaching citizens to advance rights claims' (2017b, 501). In this way, labour activists 'rather than mounting the scale of disruption... guide citizens toward direct but individual confrontation with the state, assisting workers in claiming their rights without engaging in potentially perilous protests (2017b, 502). While admitting that from this perspective labour NGOs may be seen as unwitting tools of state domination, Fu believes this strategy still helps '[lower] the cost of coordinating contention in a repressive state that forbids these organisations from operating,' allowing their survival and fostering the collective consciousness of the workers through a pedagogical process. 
Other scholars have remained more sceptical. Among the earliest and harshest critics, Ching Kwan Lee and Shen Yuan have accused labour NGOs of being an 'anti-solidarity machine', with their individualistic approach to labour rights allegedly undermining the emergence of a collective consciousness among Chinese workers (2011). On a similar note, back in 2005 Chloé Froissart observed that labour NGOs are 'also working for the benefit of the Partystate, to which they adhere, minimising social conflict and orienting reforms in a direction that can help the Party to maintain its power. While an integral part of the social movement of migrant workers, these organisations also delimit this social movement in their own way. These limitations are why some migrants question these NGOs' legitimacy to represent them' (2005, 11). Chan (2013), meanwhile, has noted that not all workers can benefit from the assistance of these organisations, as most NGOs rely on funding coming from overseas foundations that prefer to support the most vulnerable or exploited social groups, and thus overlook the issues faced by ordinary workers. Finally, Ivan Franceschini has argued that labour NGOs in China are undermined by a significant lack of 'social capital', which can be seen, among other things, in their difficulties to gain the trust of workers who believe that anybody who offers voluntarily to help them must have an ulterior motive' $(2014,485)$.

These criticisms have managed to polarise the field of Chinese labour studies, with 'optimist' and 'pessimist' scholars criticising each other, respectively, for wishful thinking or lacking long-term vision. Yet, in most cases 'pessimist' scholars have also acknowledged the importance of labour NGOs in assisting Chinese workers who otherwise would have been left entirely to their own devices; similarly, 'optimist' scholars do not refrain from acknowledging some shortcomings of these organisations. We believe that the two views are not necessarily in conflict. Labour NGOs are not static entities, they respond to opportunities and constraints. While some criticisms-and expectations-might hold true for a certain kinds of labour NGOs in specific times and places, the situation is varied and continually shifting. For instance, in recent years some organisations have changed their approach in a bid to overcome their limitations, thus transforming their relationship with the workers from one of subordination and dependency to one of partnership (A. Chan 2018).

\section{From Legal Mobilisation to Collective Struggle}

In the early 2010s, some labour NGOs started abandoning their traditional legalistic approach, and instead began promoting a new strategy focussed on the interests of the workers, articulated around the concept of 'collective bargaining' (jiti tanpan). Writing before the latest crackdown, Duan Yi (2015), a prominent labour lawyer based in Shenzhen, argued that Chinese labour NGOs were in the process of transforming from traditional 'service-oriented' (fuwuxing) and 'rights protection-oriented' (weiquanxing) organisations to real 'labour movement organisations' (gongyunxing zuzhi). Academics provided ample evidence of NGO intervention in collective disputes. In 2014, Chih-Jou Jay Chen followed the (attempted) involvement of Chinese labour NGOs in a protest by more than 40,000 workers in the Dongguan plant of Yue Yuen, a Taiwanese footwear company that had failed to pay social security to its employees (Chen 2015). We ourselves have tracked the involvement of labour NGOs in a case of collective mobilisation over several months between 2014 and 2015 at Lide, a footwear company based in Guangzhou that had decided to relocate production.

Some scholars have attempted to build a more comprehensive framework to account for these changes. In a recent study, Chen Feng and Yang Xuehui have argued that the new 'movement-oriented' labour NGOs promote a kind of 'displaced unionism'- 
where 'unionism' indicates 'certain unionlike roles these groups play, in contrast with many of their counterparts operating mainly as service providers, social workers, legal advisors, or advocates', and 'displaced' denotes the 'actual social location of these groups and where they perform their roles' (2017, 159). In another study, Froissart has provided an impressively detailed account of the role that labour NGOs play in promoting an authentic 'worker-led collective bargaining'-in contrast to state-sponsored 'collective negotiations' (jiti xieshang)-helping workers to design strategies to engage with employers, trade unions, and local authorities so that they can '[exercise] their rights before they are granted and by putting pressure on authorities to act as real authorities rather than representatives of a rogue state' (Froissart 2018, 13).

\section{An Interrupted Transition?}

Most likely, it was the shift of these few organisations from atomised legal mobilisation to union-like collective struggle that prompted the Chinese authorities to harshly clamp down on them. While repression was never far from the surface, with activists having to deal with harassment and surveillance on a daily basis (Fu 2017a), the latest attack poses a more fundamental challenge to labour NGOs for at least two reasons: first, it was not a local initiative, but in all likelihood part of a nationwide campaign supported by the highest echelons of the Party-state. Second, in coordination with the new Foreign NGO Management Law, this latest crackdown has threatened to cut off access to foreign funding vital for the survival of domestic labour NGOs.

However, we should not underestimate the ability of labour NGOs to adapt. It is true that some have simply stopped operating, prevented by a combination of state repression and declining financial support. Others have scaled down their activities, limiting themselves to realms deemed acceptable to the authorities, such as community building and, in some instances, individual legal mobilisation. In both cases, this has led activists-including the one cited at the beginning of the articleto go underground in the hope of keeping up their work under the radar. However, a few organisations are still continuing to support workers in collective bargaining, even if much less directly. But they are more careful in screening their cases, warning the workers about possible consequences, and staying away from politically delicate situations (Franceschini and Nesossi 2018). In the meantime, in conversations with labour NGOs, it is clear that this crisis is also forcing some activists to rethink and reinvent their strategies. Where does this leave us in the debate between pessimistic and optimistic views of labour NGOs? While the current situation does not warrant the optimism of those who see labour NGOs as the spearhead of a broader labour movement in China, we agree with Chris Chan that "we should not simply describe or understand these organisations and their members as "being mollified" (2018). It is undoubtedly true that the space of collective bargaining has narrowed, to the point that some scholars have argued that collective bargaining as a political project is dead (Friedman 2018). Still if the experience of the past two decades teaches us anything, it is that Chinese labour NGOs, in spite of their shortcomings, are resilient entities, apt at navigating the vagaries of the Chinese political landscape and taking advantage of any political opening. In following Lee's (2016) suggestions for the study of labour activism in China, we should now, more than ever, adhere to Gramsci's dictum: 'I'm a pessimist because of intelligence, but an optimist because of will' $(1963,310)$. 